\title{
BANDYMAI SU GYVŪNAIS IR GYVŪNINĖS KILMĖS INGREDIENTUૃ BEI JŲ ALTERNATYVŲ NAUDOJIMAS KOSMETIKOS PRAMONĖJE
}

\author{
Viktorija Gončarova, Danguolė Grūnovienė \\ Kauno kolegijos Medicinos fakultetas
}

Raktažodžiai: kosmetinès priemonès, bandymai su gyvūnais, gyvūninès kilmès ingredientai.

\section{Santrauka}

Pasaulyje, ypač išsivysčiusiose šalyse, kosmetikos pramoneje bandymai su gyvūnais išlieka vienu iš brutaliausių ir nehumaniškiausių metodų, išmėginant naujas kosmetines priemones ar jų ingredientus. Dar ir šiandien yra naudojami primityvūs tyrimo metodai, tokie kaip Draize ir LD50 testai. Nežinomi skaičiai gyvūnų, dažniausiai triušių, pelių ir žiurkių, yra naudojami ịvairiuose kosmetikos, asmens higienos, namų ūkio priemonių, cheminių medžiagų, medicinos preparatų saugaus naudojimo bandymuose. Reakcija ị visus šiuos produktus kiekvienai gyvybès formai yra skirtinga, todèl nèra lengva bandymais su gyvūnais surinktus duomenis pritaikyti situacijoms, kurios yra susijusios su produktų daromu poveikiu žmogaus organizmui. Cheminių medžiagų bandymų su gyvūnais metodai netenkina žmonių poreikių, o naujų atradimų alternatyvos lèmé tobulesnių metodų, kuriuose nèra naudojami gyvūnai, atsiradimą [11].

Kyla klausimas, ar kosmetikos bandymai su gyvūnais yra efektyvus būdas ištirti kosmetinių priemonių poveiki žmogaus organizmui? Ar atsižvelgiant i testuojamų gyvūnų fiziologiją galima teigti, kad tyrimų rezultatai tiks ir žmonèms?

Vis daugiau šalių draudžia kosmetinių produktų bandymus su gyvūnais. Šio tyrimo tikslas: atskleisti Lietuvos ir Latvijos vartotojų nuomonę apie bandymus su gyvūnais ir gyvūninès kilmès ingredientų naudojimą kosmetikos pramonejje. Tyrimo rezultatai rodo, kad dalyvavę apklausoje Lietuvos ir Latvijos gyventojai nepritaria bandymams su gyvūnais ir pasisako už alternatyvius metodus. Tiriamieji turi mažai informacijos apie bandymus, jų daromą žalą gyvūnams.

\section{Ivadas}

Pasaulyje, ypač išsivysčiusiose šalyse, kosmetinių priemonių bandymai su gyvūnais išlieka vienu iš brutaliausių ir nehumaniškiausių metodų, išmėginant naujas kosmetines priemones ar jų ingredientus. Produktų ir chemikalų toksiškumo tyrimai, taip pat ir kosmetinių priemonių saugumo ivertinimui, pasaulyje buvo pradèti dvidešimtojo amžiaus pradžioje. Šie tyrimai apima eksperimentus, kurie subjektyviai matuoja chemikalų keliamą dirginimą triušių akims ar odai ir nustato toksiškumą atsižvelgiant ị chemikalų dozes, kurios nužudo pusę testuojamų gyvūnų (priversti suèsti/ikvèpti/suleisti ị organizmą chemikalai). Šie primityvūs tyrimo metodai, ịskaitant Draize ir LD50 testus, dar ir šiandien yra naudojami [7].

Vis daugiau pasaulio valstybių, įskaitant ir Europos Sajungą, atsisako kosmetiniu priemonių bandymų su gyvūnais, bei su gyvūnais bandytų naujų kosmetinių priemonių pardavimo valstybės ribose. Tokius jų veiksmus lemia sparčiai besivystančios technologijos, kurių pagalba atrandami vis nauji, gyvūnų aukų ir kančių nereikalaujantys bandymų metodai.

Kosmetikos produktų bei ingredientų bandymuose, eksperimentinių gyvūnų poreikiui mažèjant, gyvūnai grožio puoselèjimo industrijoje dar naudojami. Natūralios kosmetinès priemonès tampa vis populiaresnès, bet ne kiekvienas žino, kad ị kosmetikos produktų sudètị neretai ịeina ir gyvūninès kilmès ingredientai. Gyvūninès kilmès ingredientai kosmetikos pramoneje yra naudojami ivvairiems tikslams, nuo dekoratyvinės kosmetikos iki gydomųju preparatu gamybos.

Tyrimu aiškinamasi Lietuvos ir Latvijos vartotojų nuomoné, ar kosmetikos bandymai su gyvūnais yra efektyvus būdas ištirti kosmetinių priemonių poveikị žmogaus organizmui? Ar atsižvelgiant ị testuojamų gyvūnų fiziologiją galima teigti, kad tyrimų rezultatai tiks ir žmonėms? Kokios egzistuoja bandymų su gyvūnais alternatyvos ir kodèl dèl jų (alternatyvų) kosmetikos priemonių bandymų su gyvūnais jau atsisako pasaulio valstybès? Aptariami kosme- 
tikos pramonèje naudojami gyvūninės kilmès ingredientai, jų daromas poveikis žmogaus odai bei aprašomos ne gyvūninès kilmès ingredientų alternatyvos.

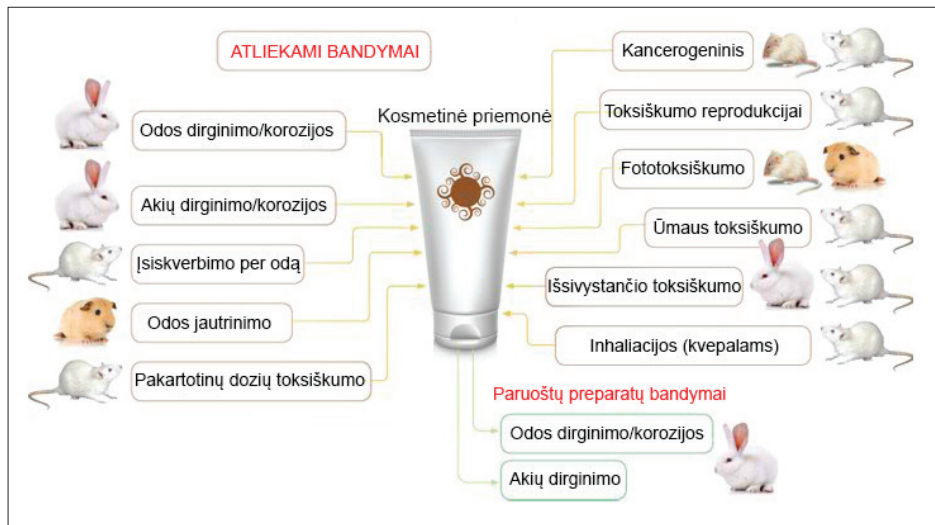

1 pav. Kosmetikos priemonių bandymams naudojami gyvūnai ir metodai

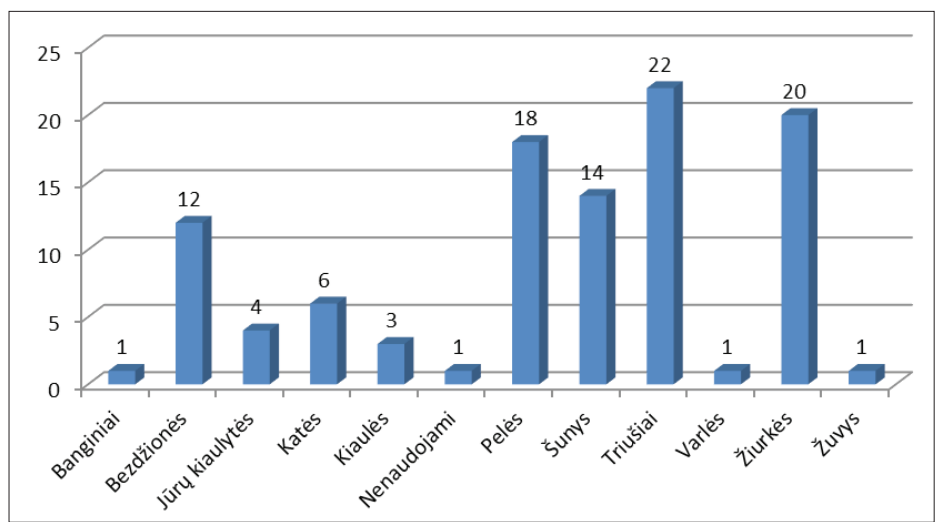

2 pav. Lietuvos respondentų nurodyti kosmetikos bandymams naudojami gyvūnai

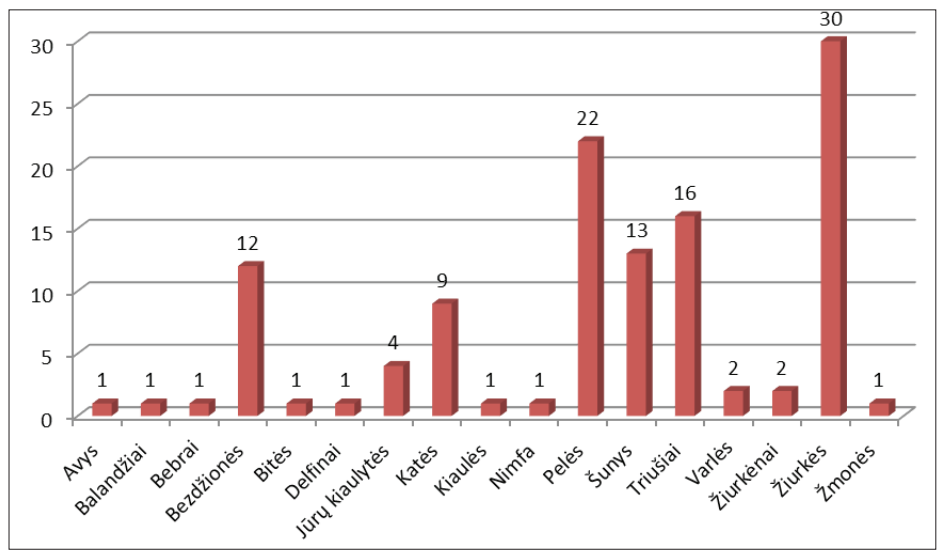

3 pav. Latvijos respondentų nurodyti kosmetikos bandymams naudojami gyvūnai
Tyrimo tikslas: atskleisti Lietuvos ir Latvijos vartotojų nuomonę apie bandymus su gyvūnais ir gyvūninès kilmès ingredientų naudojimą kosmetikos pramonèje.

\section{Tyrimo objektas ir metodika}

Tyrimo objektas - vartotojų nuomonè. Tiriamieji parinkti, kad tenkintų kiekybinių tyrimų atlikimo reikalavimus. Apklausta 100 (50 Lietuvos ir 50 Latvijos) įvairaus amžiaus kosmetikos priemonių vartotojų. Tema labiau sudomino 21 - 40 metų amžiaus studentes ir/ar dirbančias moteriškos lyties tiriamąsias: nes išanalizavus lietuvių ir latvių respondentų duomenis, atsakiusius į anketoje pateiktus klausimus, $89 \%$ visų respondentų sudaro moterys (47 Lietuvos ir 42 Latvijos).

Tyrimo metodai: mokslinès literatūros analizè; anketinė apklausa; statistinė duomenų analizè. Statistiniam tyrimo duomenų apdorojimui buvo naudojama Microsoft Excel programa, kurioje duomenys analizuojami modeliuojant grafikus.

Internetinių apklausų tinklalapiuose (apklausa.lt ir eSurveysPro.com) sudarytos anketos lietuvių bei rusų kalbomis. Tyrimui atlikti buvo naudota anoniminè anketinè apklausa, kurioje pateiktas 21 klausimas, išskiriant 3 dalis:

1. Vartotojų nuomonè apie bandymus su gyvūnais, bandymų alternatyvos (1-7 klausimai).

2. Vartotojų nuomonė apie bandymų su gyvūnais uždraudimą (8-9 klausimai).

3. Vartotojų nuomonè apie gyvūninès kilmès ingredientus bei jų alternatyvas, naudojamus kosmetikos pramonèje (10-21 klausimai).

Dažniausiai kosmetikos pramonejje atliekamiems bandymams naudojami triušiai, pelès, žiurkès ir jūrų kiaulytès, bet eksperimentai atliekami ir su kitomis gyvūnų rūšimis (pvz:: šunys, katès, primatai) (1 pav.).

Bandymai su gyvūnais atliekami keturiose srityse: vaistinių preparatų bandymuose, fundamentaliuosiuose moksliniuose tyrimuose (iskaitant karinius, medicinos, kosmoso ir kt.), kosmetinių priemonių bandymuose ir gyvūnų naudojimo mokymo procese. Kosmetinių priemoniu testavimas - tai ta sritis, kurioje negalima akcentuoti eksperimentų būtinybės, siekiant išsaugoti žmonių gyvybę ar sveikatą, nes gyvūnai aukojami išskirtinai tik dèl žmonių užgaidų. Šiuo metu jau yra siūlomi alternatyvūs modeliai tyrimams visose srityse.

Kyla klausimas dèl bandymų su eksperimenti- 
niais gyvūnais efektyvumo, kadangi gyvūnų ir žmogaus fiziologija skiriasi bei medžiagu apykaitos procesai jų organizmuose vyksta skirtingai. Pasaulio gydytojų judejjimas, palaikantis eksperimentinio mokslo modernizavimą ir alternatyvų paiešką, šiuo metu ịgauna pagreitị, vis daugiau valstybių uždraudžia kosmetikos priemonių ir ingredientų bandymus su gyvūnais.

Europos Sajunga (ES) - pirmoji pasaulyje 28 šalių sajunga, uždraudusi kosmetikos priemonių bandymus su gyvūnais. 1993 metais ES priimta direktyva nurode kosmetikos priemonių, bandytų su gyvūnais, rinkodaros uždraudimą, kuris įsigaliojo 1998 metais. Pirmoji bandymus su gyvūnais uždraude ES šalis Didžioji Britanija, o Indija tapo pirmąja Azijos šalimi, uždraudusia šiuos bandymus. Jungtinès Amerikos Valstijos, Australija, Naujoji Zelandija šį draudimą dar svarsto.

İvairūs moksliniai literatūros šaltiniai nurodo šiuos dažniausiai naudojamus gyvūninès kilmès ingredientus ir jų alternatyvas.

Alfa hidroksi rūgštys. Bet kuri iš kelių rūgščių naudojama kaip eksfoliantas ir priešraukšlinis produktas. Pieno rūgštys gaunamos iš gyvūnų. Produktai, kurių sudetyje yra AHA, naudojami raukšlių lyginimui, jaunatvinių spuogų gydymui, randelių šalinimui, odos tekstūros ir tonuso gerinimui, poru valymui bei odos būklès gerinimui. Kartais šios rūgštys naudojamos kosmetikoje ir dèl kitų priežasčiu, pavyzdžiui, $\mathrm{pH}$ reguliavimui (rūgštingumo ar šarmingumo laipsnio reguliavimui). Produktai, kuriuose yra AHA, sukelia eksfoliaciją (odos raginio sluoksnio lupimąsi). Eksfoliacijos lygis priklauso nuo AHA kiekio, koncentracijos, $\mathrm{pH}$ ir kitų ingredientų, ieinančiu i produkto sudetti. Galimi šalutiniai AHA poveikiai: nudegimas, dermatitas ar bèrimas, tinimas, pigmentacijos pokyčiai, odos lupimasis, niežulys, odos dirginimas ar jautrumas, cheminiai nudegimai ir padideję̧s jautrumas saulès spinduliams [9]. Alternatyvos: glikolio rūgštis, citrinos rūgštis ir salicilo rūgštis [6].

Amino rūgštys. Baltymų darinys, randamas visuose gyvūnuose ir augaluose. Naudojamas kosmetikos pramoneje (jauninančiose kosmetinėse priemonėse), vitaminuose, šam- pūnuose, maisto papilduose bei kt. Kosmetikos priemonėse naudojamas keturių amino rūgščiu, skatinančiu kolageno gamybą, derinys: prolino, glicerino, leucino ir lizino, kuris veikia kaip eksfoliatorius ir antioksidantas, gerina drègmès išlaikymą odoje, bendrą odos tekstūrą, mažina randus ir amžiaus pigmentines dèmes. Šios medžiagos neveikia raukšlių. Kosmetikos priemonèse esančių amino rūgščiu poveikis odai vienodas nepriklausomai kaip baltymas yra išgautas - iš gyvūnų ar iš alternatyvių šaltinių [10].

Gyvūnų riebalai. Naudojant kosmetikos priemonėse, drèkina ir maitina odą [2]. Alternatyvos: alyvuogių, grūdų gemalų, kokoso, linų sėmenų, migdolų aliejai.

Karminas. Košenilis. Karmino rūgštis. Raudonas pigmentas, gaunamas iš susmulkintų košenilio vabzdžių patelių (nužudant apie 70000 vabalų tam, kad išgautume pusę kilogramo šio raudono dažo). Naudojamas kosmetikos priemonèse (nagų lakuose, lūpų dažuose, akių, lūpų

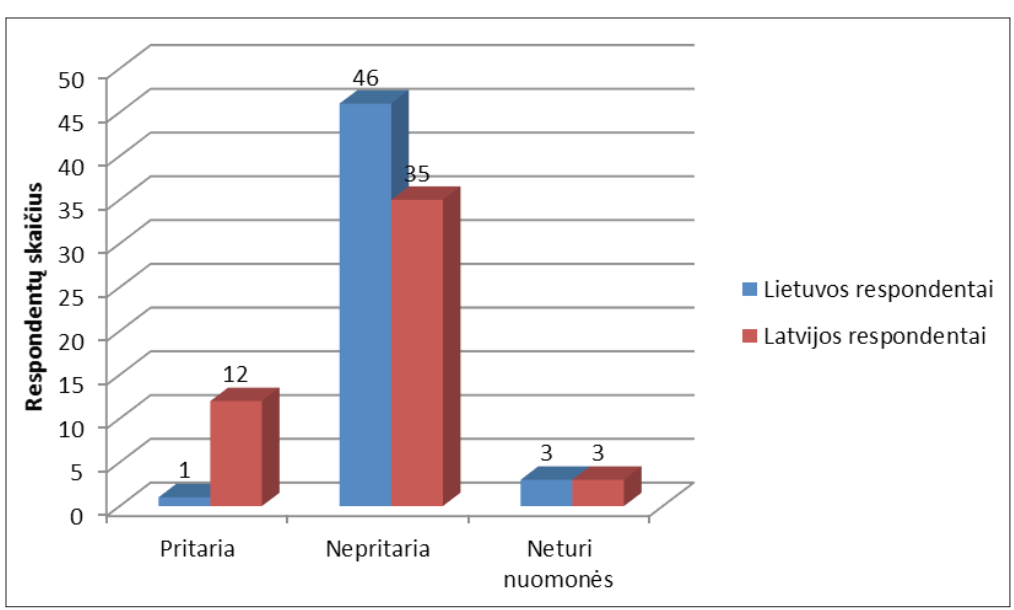

4 pav. Vartotojų nuomonė apie kosmetikos produktų ir ingredientų bandymus su gyvūnais

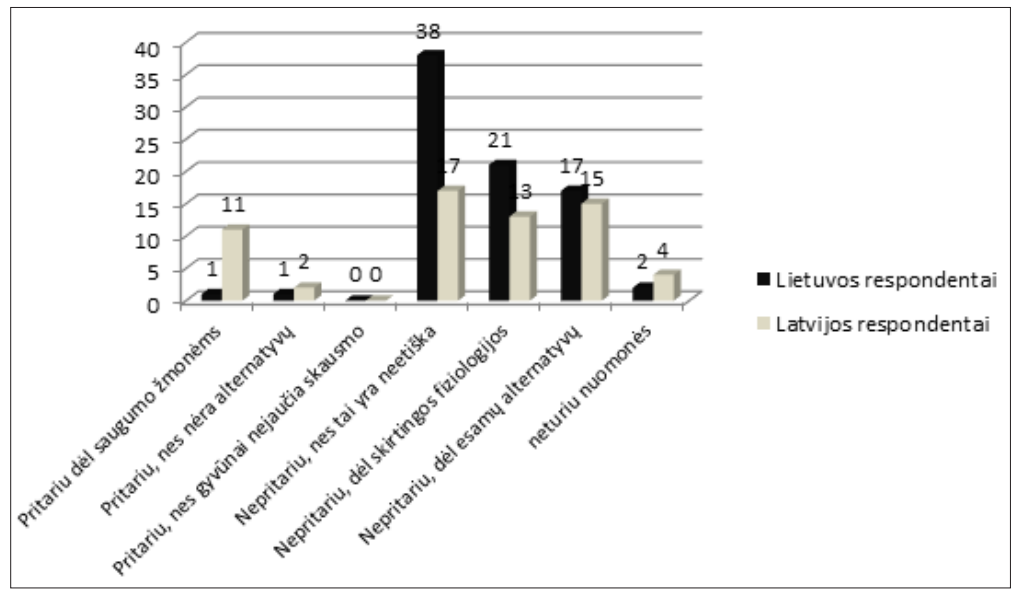

5 pav. Vartotojų nuomonė apie kosmetikos priemonių ir ingredientų bandymų su gyvūnais reikalingumą 


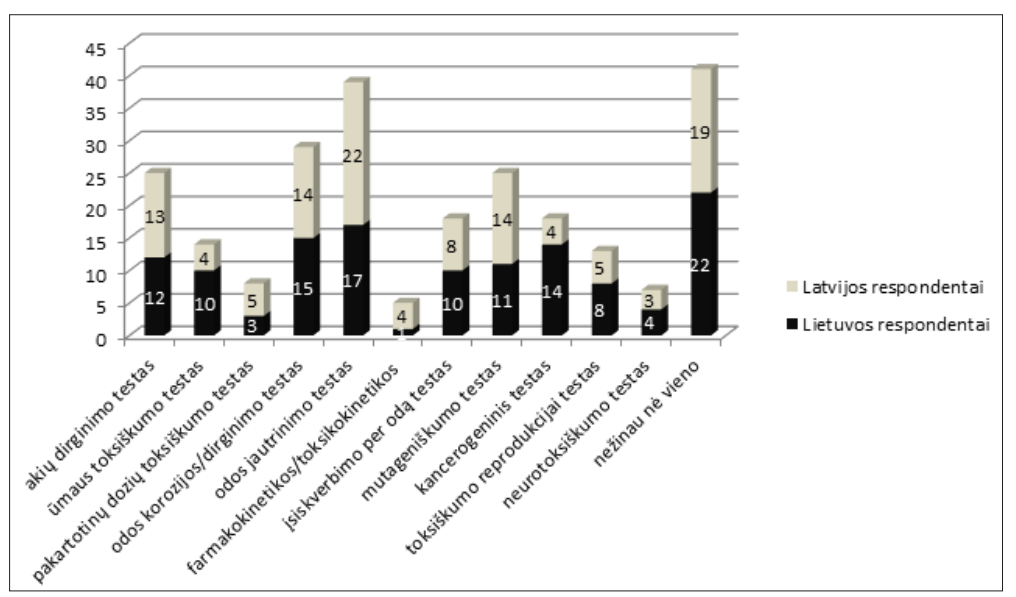

6 pav. Vartotojų žinios apie kosmetikos priemonių ir ingredientų bandymus atliekamus su gyvūnais

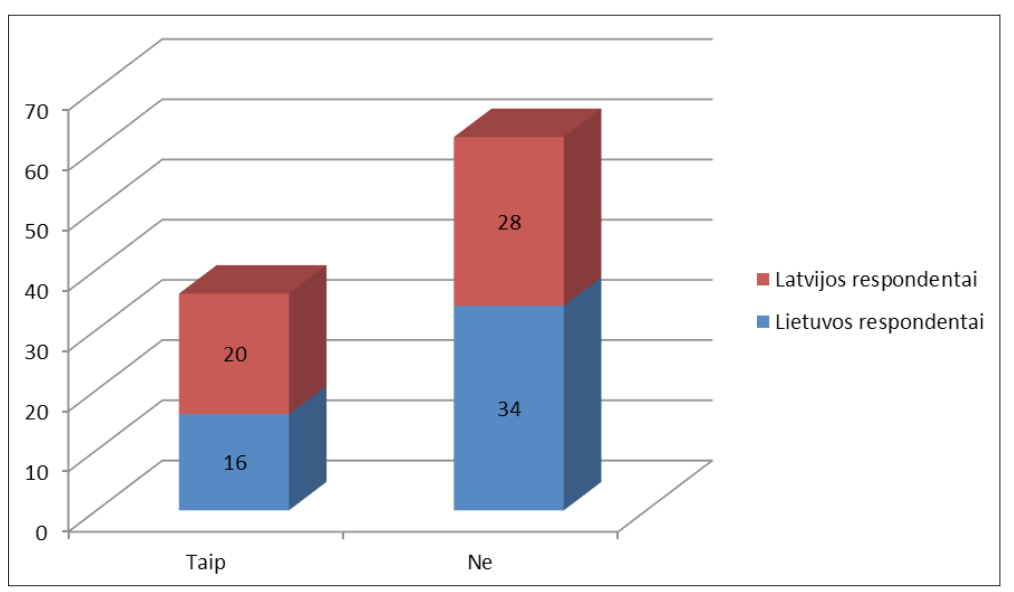

7 pav. Vartotojų žinios apie kosmetikos produktų ir ingredientų bandymų su gyvūnais alternatyvius metodus

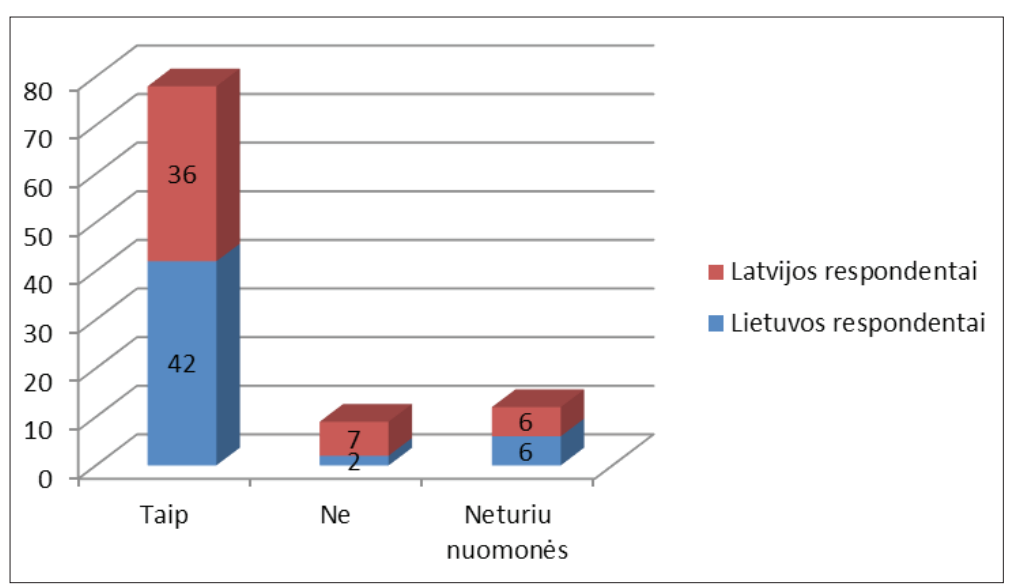

8 pav. Vartotojų nuomonė apie bandymų su gyvūnais uždraudimo poreikị kontūro pieštukuose, lūpų blizgiuose, šešèliuose, pudroje ir lūpų balzamuose), šampūnų, maistinių dažų gamyboje. Gali sukelti alergines reakcijas [5]. Alternatyvos: burokèlių sultys, alkaneto šaknys.

Kolagenas. Pluoštinis stuburinių gyvūnų baltymas (dažniausiai išgaunamas iš gyvūnų audinių), alergenas. Kosmetikos priemonèse kolagenas naudojamas pagerinti vandens išlaikymą odoje. Kremai su kolagenu veikia tik odos paviršių, kaip ir kiti drèkinamieji kremai, jie išlaiko odos drègmę ir padeda išlaikyti jos elastingumą [10]. Alternatyvos: sojos baltymai, migdolų aliejus.

Elastinas. Baltymas, randamas karvių kaklo raiščiuose ir aortose. Kaip ir kolagenas, elastinas kosmetikos priemonèse naudojamas odos drègmei palaikyti [10]. Alternatyvos: sintetiniu būdu išgauti baltymai, augalų audinių baltymai.

Želatina. Želè. Baltymas, gaunamas vandenyje verdant kiaulių, karvių odą, sausgysles, raiščius ir/ar kaulus. Želatina naudojama: veido kremuose, kūno losjonuose, šampūnuose, plaukų priežiūros, apsaugos nuo saulès spindulių priemonèse, vonios druskose, putose kaip tirštinantis ingredientas. Gali sukelti alergines reakcijas [10]. Alternatyvos: karagenas (airiška samana), jūriniai vandens augalai, pektinas, dekstrinas. Šie ingredientai veikia kaip tirštinamasis agentas, jų pagalba kosmetinès priemonès išlaiko savo konsistenciją.

Hialurono rūgštis. Baltymas, randamas bambagysleje ir sąnarių skysčiuose. Naudojamas kosmetikoje (odos priežiūros produktuose, lūpų dažuose, makiažo priemonèse), asmens higienos produktuose. Pagerina sausos ar pažeistos odos išvaizdą, sumažina odos šerpetojimą ir atkuria jos elastingumą, gerina odos drègmès lygị, sumažina uždegimą, sulaiko drégmę odoje [8]. Alternatyvos: sintetiniu būdu išgauta hialurono rūgštis, augaliniai aliejai.

Lecitinas. Cholino bitartratas. I vašką panaši gyvų organizmų nervinio audinio medžiaga. Lecitinas naudojamas paakių kremuose, lūpų dažuose, rankų kremuose, losjonuose, muiluose, šampūnuose ir kitose kosmetinèse priemonèse. Jis gerina sausos 
ar pažeistos odos išvaizdą, mažina jos pleiskanojimą ir atkuria elastingumą. Gali sukelti odos jautrumą [6]. Alternatyvos: sojos lecitinas, sintetiniu būdu išgautas lecitinas.

Oleino rūgštis. Gaunama iš įvairiu gyvūnų ir augalų riebalų ir aliejų. Naudojama kosmetikos pramoneje, gaminant muilus, kremus, nagų lakus, lūpų dažus ir kitus odos preparatus. Oleino rūgštis veikia kaip emolientas, drékina odą [5]. Alternatyvos: kokosų, alyvuogių, linų sėmenų, migdolų aliejai ir kt.

Placenta. Placentos polipeptidu baltymai. Gaunama iš paskerstų gyvūnų gimdų. Gyvūnų placenta yra plačiai vartojama odos kremuose, šampūnuose, veido kaukèse ir kt. Placentos ekstraktuose yra enzimų, nukleino rūgščių, vitaminų, amino rūgščių, steroidų ir mineralų, kurie lètina odos senejjimą, skatina audinių augimą, pašalina raukšles, pagerina ląstelių regeneraciją ir imuninę sistemą. Placenta yra baltymų ir hormonų, estrogeno ir progesterono šaltinis kosmetikos produktuose [4]. Alternatyvos: rudadumbliai, kokosu aliejus, alyvuogių aliejus, linų sėmenų aliejus, migdolų aliejus [8].

Ryklių kepenų aliejus. Skvalanas ir skvalenas. Aliejus gaunamas iš ryklių kepenų. Skvalanas ir skvalenas yra naudojami kaip vonios aliejų, plaukų produktų, akių makiažo, makiažo pagrindo, lūpų dažų, įdegio ir apsaugos nuo saulès spindulių produktų, kūno pudrų, nagų produktų, valiklių, drékiklių ir odos priežiūros produktu ingredientai. Jie lubrikuoja odos paviršių, padeda išlaikyti odos drègmę, daro odą minkštą ir suteikia lygumo [3]. Alternatyvos: augaliniai emolientai - alyvuogių, kviečių gemalų, ryžių sẻlenų aliejai.

Steroidai. Steroliai. Gaunami iš įvairių gyvūnų liaukų ar audinių. Naudojami kremuose, losjonuose, plaukų kondicionieriuose, kvepaluose. Turi šviesinamaji poveikį, todèl kremai su steroidais yra naudojami pigmentinių dėmių šviesinimui, ma-

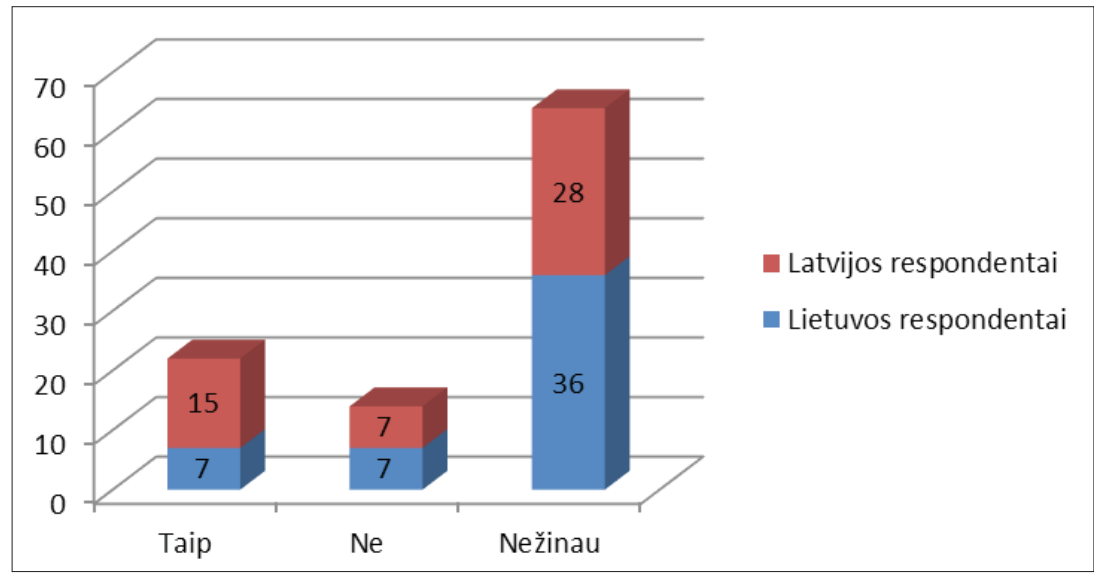

9 pav. Vartotojų žinios apie kosmetikos priemonių bandymų su gyvūnais uždraudimą ES

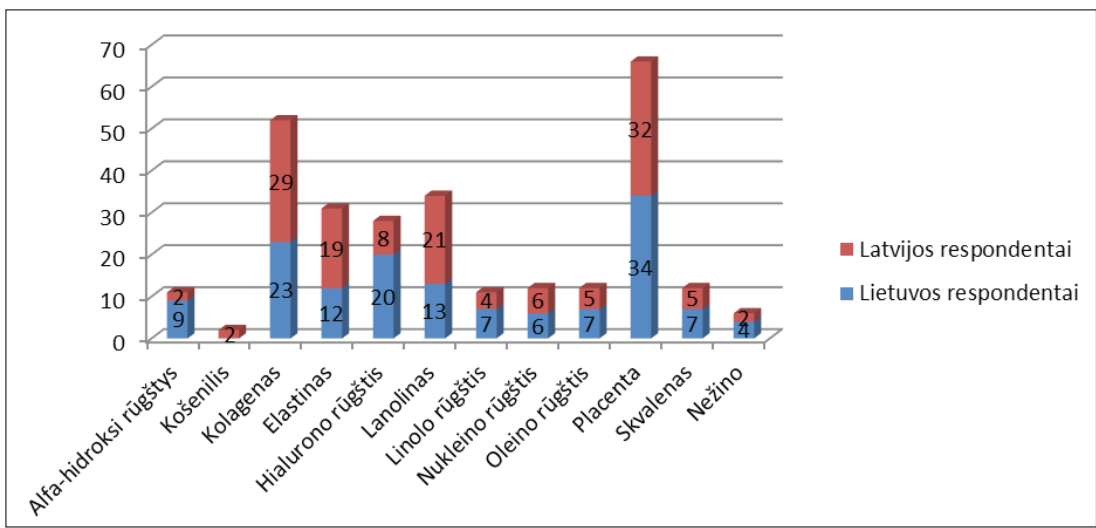

10 pav. Vartotojų žinios apie populiariausius gyvūninės kilmės ingredientus, naudojamus kosmetikos pramonèje

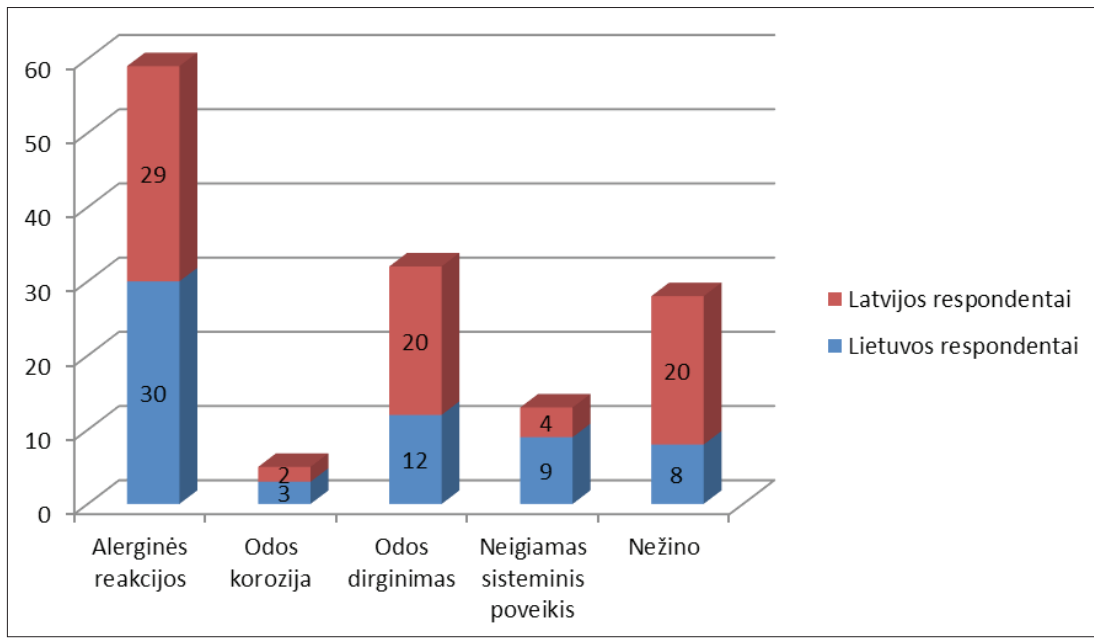

11 pav. Gyvūninès kilmès ingredientų kosmetinėse priemonėse pašalinis poveikis 
žina odos pleiskanojimą ir atkuria elastingumą [1]. Alternatyvos: augaliniai audiniai, sintetiniai steroidai [9].

\section{Tyrimo rezultatai ir jų aptarimas}

Apklausos metu gauti duomenys rodo, kad kosmetikos priemonių bei ingredientų bandymams naudojamus gyvūnus Lietuvos ir Latvijos respondentai ịvardijo: 50\% žiurkes (20 Lietuvos ir 30 Latvijos), 40\% peles (18 Lietuvos ir 22 Latvijos) ir 38\% triušius (22 Lietuvos ir 16 Latvijos). Respondentai nurodè, kad bandymams naudojami šunys (27\% respondentu), beždžionès (24\% respondentu)), katès (15\% respondentų) ir jūrų kiaulytès $(8 \%$ respondentų). Verta paminèti, kad kai kurie respondentai nurodè su kosmetikos priemonių bei ingredientų bandymais nesusijusius gyvūnus, tokius kaip kiaulès (4\% respondentų), varlès (3\% respondentų), banginiai, balandžiai, avys, bebrai, delfinai ir nimfos (po 1\% respondentu). Vienas Lietuvos respondentas išreiškè nuomonę, kad kosmetikos priemonių bandymams gyvūnai nèra naudojami, o vienas Latvijos respondentas nurode, kad kosmetikos priemonių bandymai yra atliekami su žmonèmis (savanoriški kosmetinių priemonių bandymai su žmonèmis gali būti atliekami tik po to, kai kosmetiné priemone ir jos ingredientai buvo išbandyti su gyvūnais ar alternatyviais bandymo metodais ir išsiaiškinta, kad žmonèms bandomają kosmetinę priemonę vartoti yra saugu) (2,3 pav.).

Dauguma Lietuvos ir Latvijos respondentu (81\%, 46 Lietuvos ir 35 Latvijos) nurodè, kad kosmetikos priemonių ir ingredientų bandymams su gyvūnais jie nepritaria. $13 \%$ - bandymams su gyvūnais pritaria, dauguma Latvijos respondentai (1 Lietuvos ir 12 Latvijos) (4 pav.).

Analizuojant nuomonę apie kosmetikos priemonių ir ingredientų bandymų su gyvūnais reikalingumą paaiškejjo, kad daugiausia tiriamujų nepritaria, nes jų manymu, tai yra neetiška ir nehumaniška (55\%, 38 Lietuvos ir 17 Latvijos) dèl skirtingos gyvūnų bei žmonių fiziologijos (34\%, 21 Lietuvos ir 13 Latvijos) bei dèl esamų kosmetikos priemoniu bandymų su gyvūnais alternatyvu (32\%, 17 Lietuvos ir 15 Latvijos). Kosmetikos priemoniu ir ingredientu bandymams su gyvūnais pritariantys respondentai teigia, kad bandymai yra reikalingi užtikrinant saugų kosmetikos naudojimą žmonèms (12\%, 1 Lietuvos ir 11 Latvijos), o mažuma mano, kad bandymams su gyvūnais nèra lygiaverčiu alternatyvų (3\%, 1 Lietuvos ir 2 Latvijos). Nè vienas respondentas, pritariantis bandymams su gyvūnais, nesutinka, kad gyvūnai skausmo nejaučia (5 pav.).

Labiausiai respondentams žinomi bandymai - odos jautrinimo (39\%, 17 Lietuvos ir 22 Latvijos), odos korozijos/dirginimo (29\%), akių dirginimo ir mutageniškumo $(25 \%)$, ịsiskverbimo per odą ir kancerogeninis (18\%), ūmaus toksiškumo (14\%), toksiškumo reprodukcijai testai (13\%). Mažiausiai tarp apklaustujų žinomi pakartotinių dozių toksiškumo (8\%), neurotoksiškumo (7\%) ir farmakokinetikos/toksikokinetikos (5\%) bandymai (6 pav.).

Daugiau nei pusè respondentų (62\%, 34 Lietuvos ir 28 Latvijos) nežino apie kosmetikos priemonių ir ingredientų bandymų su gyvūnais alternatyvius metodus. Tokius rezultatus galèjo nulemti tai, jog yra informacijos stygius apie alternatyvius kosmetikos produktų ir ingredientų bandymų metodus, ką teigia $60 \%$ respondentu (30 Lietuvos ir $30 \mathrm{La}-$ tvijos), daugiau nei trečdalis (19 Lietuvos ir 17 Latvijos) šiuo klausimu tiesiog nesidomejjo ir tik maža dalis (4\%) respondentų mano, kad informacijos apie kosmetikos priemonių ir ingredientų bandymus su gyvūnais bei alternatyvius bandymo metodus visiškai pakanka (7 pav.).

Pagrindinè kosmetikos priemonių ir ingredientų bandymų su gyvūnais uždraudimo priežastis - neseniai ịstatymais patvirtintas bandymų su gyvūnais ir naujai bandytos su gyvūnais kosmetikos marketingo uždraudimas Europos Sąjungoje. Didžioji dauguma respondentų (78\%, 42 Lietuvos ir 36 Latvijos) pritaria kosmetikos priemonių ir ingredientų bandymų su gyvūnais uždraudimui ir tik $9 \%$ apklaustųjų mano, kad bandymai neturètų būti draudžiami (8 pav.).

Europos Sajungoje ịsigaliojus kosmetikos priemonių ir ingredientų bandymų su gyvūnais draudimui, informacijos sklaidos buvo nedaug. Dèl šios priežasties tik ketvirtadalis respondentų žino apie ši Europos Komisijos (EK) sprendimą. Daugiausia apklaustujų (64\%, 36 Lietuvos ir 28 Latvijos) pasisakè nežinantys apie tokị draudimą, o likusieji teigè, kad tokio draudimo išvis nèra ( 9 pav.).

Labiausiai žinomas gyvūninès kilmès kosmetinių priemonių ingredientas yra placenta, tai nurodè du trečdaliai, kolageną žino daugiau nei pusė respondentų, elastiną, lanoliną, hialurono rūgšti - trečdalis. Mažiausiai vartotojų dẻmesio susilaukè natūralus raudonos spalvos pigmentas - košenilis, ji paminèjo tik du apklausoje dalyvavę respondentai (10 pav.).

Apie kosmetinèse priemonèse esančių gyvūninès kilmès ingredientų sukeliamą pašalinį poveiki daugiau nei pusė respondentų neturejjo nuomonès $(52 \%, 25$ Lietuvos ir 27 Latvijos), bet nemaža dalis (42\%) mano, kad gyvūninès kilmès ingredientai gali sukelti šalutini poveikị: alergines reakcijas, odos dirginimą, gali pasireikšti sisteminis poveikis, o maža dalis galvoja, kad jo būti negali (11 pav.).

\section{Išvados}

Kosmetikos produktų ir ingredientų bandymai su gyvūnais pamažu praranda populiarumą. Dėl kintančios žmonių pasaulèžiūros ir tobulèjančių alternatyvių bandymų metodų vis daugiau pasaulio valstybių uždraudžia bandymus su gy- 
vūnais. Alternatyvūs bandymų metodai ne tik nereikalauja (arba reikalauja mažiau) gyvūnų aukų, bet ir gaunami rezultatai yra tikslesni ir labiau patikimi.

Kosmetikos pramonèje naudojami ịvairūs gyvūninès kilmès ingredientai. Jų poveikis žmogaus odai yra akivaizdus, bet dauguma šių ingredientų gali sukelti ir nepageidaujamų poveikių. Kiekvienas gyvūninès kilmès ingredientas turi kelias ne gyvūninès kilmès alternatyvas, kurios daro toki pat ar net geresni poveiki odai, be to, naudojant juos yra mažesnè šalutinių poveikių tikimybè.

Lietuvos ir Latvijos vartotojai nepritaria bandymams su gyvūnais kosmetikos pramoneje. Jie žino apie kosmetikos pramoneje naudojamus bandymus su gyvūnais, gyvūninès kilmès ingredientus kosmetinèse priemonèse ir galimą jų šalutini poveikį. Apie bandymų su gyvūnais alternatyvas respondentai informacijos turi minimaliai, kadangi jos nèra daug ir mažai reklamuojama.

\section{Literatūra}

1. Are Steroids Dangerous? [interakytvus]. 2012-02-07 [žiūrèta 2015-04-03]. Prieiga per interneta: < http://www.dermletter. com/skin-care-science/are-steroids-dangerous.html $>$

2. Berdick Murray. The role of fats and oils in cosmetics. Iš Journal of the American Oil Chemists' Society [interaktyvus]. 1972 [žiūreta 2015-04-02]. Prieiga per internetą: <A38http://link. springer.com/article/10.1007/BF02582522\#page-1>

3. Dermatologų bendrija. Iš TheDermView [interaktyvus]. 201007-02 [žiūrèta 2015-04-03]. Prieiga per internetą: $<$ http://www. thedermreview.com/squalane/>

4. Effendi Bin Shuib Shahril. Placenta for cosmetic purpose and cell regeneration. iš health technology assessment section medical development division ministry of health malaysia 021/2013. [žiūrèta 2015-04-

5. European Commission. Health and Consumer CosIng. [žiūrèta 2015-04-06]. Prieiga per internetą: <http://ec.europa.eu/ consumers/cosmetics/cosing/index.cfm?fuseaction=search. details\&id $=55327 \&$ back $=1>$.

6. Kosmetinių priemonių ingredientų duomenų bazè [interaktyvus]. [žiūrèta 2015-04-02]. Prieiga per internetą: $<$ http://cosmeticsinfo.org $/$ search $/$ node $/ \mathrm{I} \% 27 \mathrm{~m} \% 20$ Looking\%20For...>.

7. Nacionalinè Anti-vivisekcijos draugija. Animals in Science [interaktyvus]. 2015-01-03 [žiūrèta 2015-04-10]. Prieiga per internetą: <http://www.navs.org/science/animals-in-producttesting $>$.

8. New Heath Guide sveikatos priežiūros duomenų bazè [interaktyvus]. [žiūretta 2015-03-22]. Prieiga per internetą: <http://www. newhealthguide.org/Almond-Oil-For-Skin.html> .
9. Oakley Amanda. Bleaching Creams. [interaktyvus]. 2014-04-05 [žiūrèta 2015-04-02]. Prieiga per interneta: $<$ http://dermnetnz. org/treatments/bleach.html>.

10. PC kosmetinių ingredientų duomenų bazè [interaktyvus]. [žiūrèta 2015-04-03]. Priega per internetą: <http://www.paulaschoice. com/cosmetic-ingredient-dictionary/>.

11. Schaeffer Crystal. Product Testing: begining to an end? Iš ConsumerPowerforAnimals [interaktyvus]. 2010 - [žiūrèta 2015-02-17]. Prieiga per internetą: <http://aavs.org/animalsscience/how-animals-are-used/testing/>. ISSN 0274-7774.

\section{TESTING ON ANIMALS, USAGE OF ANIMAL DERIVED INGREDIENTS AND THEIR ALTERNATIVES IN COSMETICS INDUSTRY}

\section{Gončarova, D. Grunovienè}

Key words: cosmetic products, experiments with animals, animal derived ingredients.

Summary

Testing on animals remains one of the most brutal and inhumane methods of testing cosmetic products or ingredients in nowadays world, even in highly developed countries. Countless number of animals, mostly rabbits mice and rats are used in various testing of cosmetics, personal hygiene products, household products, chemical substances and medications in order to check their safety for usage. Reactions of each form of life to all these products differ. Therefore, it is not easy to apply data gathered from animal testing in situations related to impact of products on the human body. Testing chemical substances on animals does not satisfy human needs and newly discovered alternatives suggest more advanced methods in which animals are not used.

The question arises whether cosmetics testing on animals is efficient way to investigate the impact of cosmetic production on human body. What is more, can it be stated that taking into account physiology of animals tested the research results will be applicable to humans?

More and more countries decide to ban cosmetic products testing on animals. The aim of this research is to reveal the opinion of Lithuanian and Latvian consumers on animal testing as well as using animal derived ingredients in cosmetics industry. The results of the research show that residents of Lithuania and Latvia do not support testing on animals and prefer alternative methods.

It must be noted, however, that the surveyed respondents had little knowledge of testing and its impact on animals.

Correspondence to: danguole.grunoviene@go.kauko.lt

Gauta 2015-09-07 